\title{
The Implementation of Online Learning Policy at Tirta Kencana Elementary School
}

\author{
Duha Goiri $^{*}$, Edi Harapan ${ }^{2}$, Tahrun ${ }^{2}$
}

\author{
${ }^{1}$ Teacher of SDN 11 Makarti Jaya \\ ${ }^{2}$ Universitas PGRI Palembang \\ *Corresponding author. Email: duhago25@gmail.com
}

\begin{abstract}
With the issuance of Circular Letter of the Minister of Education and Culture No. 4 of 2020, all schools conduct distance learning, both online and offline. The purpose of this research was to find out the implementation of online learning in Tirta Kencana Elementary School in Makarti Jaya sub-district. The type of research was qualitative research with the case study method. Data collection were interviews, observations, and documentation. From the results of the research, it can be concluded that the implementation of online learning in Tirta Kencana Elementary School went well, starting from planning, implementing, evaluating, preparing media, teaching materials, and learning resources. In the implementation, lack of signals, frequent power outages and did not have an android handphone. The solution to that problem is that teachers do offline learning for students who are constrained when learning online.
\end{abstract}

Keywords: Online Learning, Education Policy, Policy Implementation

\section{INTRODUCTION}

The implementation of home learning during the Covid-19 pandemic has finally been carried out in schools in Indonesia. This policy is based on the Circular Letter of the Minister of Education No. 4 of 2020 on the Implementation of Education Policy in the Emergency Period of the Spread of Covid-19. Following up on the Circular Letter of the Minister of Education and Culture, the Banyuasin government also issued a Circular Letter of the Banyuasin Regency Number 440 of 2020 on the implementation of education policies in the emergency period of the spread of Covid-19. With the issuance of the Circular Letter of the Banyuasin Regency, all schools in Banyuasin district conduct learning from home, including elementary schools in Tirta Kencana village, Makarti Jaya sub-district, Banyuasin Regency.

Previous research conducted by Ayuni et. al. were also discussed the problem of online learning [1]. They discussed the impact of online learning, while this study discusses the implementation of online in Tirta Kencana elementary school. Besides, Erwin et.al researched the utilization of ITC in the learning process [2].

Geographically, Tirta Kencana elementary school is located in a water area that is far from the city and there is no road access connecting to this area. It is located on a delta-shaped island. Although it is located in a place that far from the city, but all elements that run the education of both teachers and principals have a high commitment to improving education in the region. With various limitations and shortcomings, the teachers continue to carry out appeals from the government to conduct online learning even though the implementation is found many obstacles.

\section{METHODS}

This research was conducted in Tirta Kencana Elementary School in Makarti Jaya sub-district, Banyuasin, South Sumatra province. The research method used in this research is qualitative with the case study method. Researchers chose this method because the researchers wanted to dig up information in Tirta Kencana elementary school that could eventually be learned from a case, from which the case would be gained further knowledge and scientific depth.

Case studies are a series of scientific activities carried out intensively, detailed and in-depth about a program, event, and activity, whether at the level of individuals, groups of people, institutions, or organizations to gain in-depth knowledge of the event. Typically, selected events that are hereinafter referred to as cases are actual, ongoing, not past. Then, there are some techniques used in collecting the data, i.e. interview, documentation, observation, and physical artifacts. Each to complement each other.

\section{RESULTS AND DISCUSSION}

\section{Online Learning}

Online learning is an electronic-based learning process [3]. One of the media used is smartphone and computer networks. The development of information technology has a big influence on changes in each field and human life. One of them is the change in education. 
Technology can be utilized in teaching and learning activities, which can be said to be a shift from conventional to modern. Rahayu and Wirza; and AlMaqtri mentioned that some research shows that the presence of technology has a lot of positive influence on learning [4] [5]. In Tirta Kencana Elementary School, Makarti Jaya sub-district, Banyuasin, the internet has been used in learning activities. Online learning is a learning system that is done not face-to-face but using a platform that can help the teaching and learning process that is done remotely. Teachers and students in Tirta Kencana Elementary School, Makarti Jaya sub-district, Banyuasin, did online learning by using some platforms such as WhatsApp application. Sofyana states the purpose of online learning is to provide quality learning services in a massive network that is open to reaching more and wider learning space enthusiasts [6]. According to Hasanah, the challenge of online learning is the expertise in the use of technology from educators and learners [7].

\section{Implementation of Education Policy}

According to Tilaar, education policy is the whole process and results of the formulation of strategic educational steps as outlined in the vision and mission of education, to achieve the achievement of educational goals in society for a certain period [8]. Besides, he argued that education policy is a public policy that regulates specific regulations related to the absorption of sources, allocation and distribution of sources, and regulation of behavior in education [9]. Policy implementation is a process of implementing or executing a program or policy. Policy implementation has three pillars in running or implementing the program. The three pillars are organization, achievement, and implementation. According to Rohman, the process of implementing education policy involves political, social, legal, and administrative/organizational instruments to achieve successful implementation of educational policies [9]. So, online learning is something to be or not to be [10]. In Tirta Kencana Elementary School, Makarti Jaya subdistrict, Banyuasin, sometimes online learning couldn't used optimally, because of connectiona problems and the facilities owned by students.

\section{CONCLUSION}

Based on the results of the research, it can be concluded that in the implementation of online learning in elementary school Tirta Kencana Makarti Jaya subdistrict is running well with the findings in learning planning, implementation of learning, use of learning media, teaching materials and learning resources, evaluating learning outcomes and providing solutions to obstacles when learning online is good. To improve the quality of education and achieve the educational objectives of a teacher in conducting online learning should prepare the learning well, carry out learning according to the guidelines, conduct evaluations, utilize learning media, use teaching materials and learning resources from anywhere, and provide appropriate solutions to the constraints on learning.

\section{REFERENCES}

[1] Ayuni, D., Marini T., Fauziddin, M., \& Pahrul, Y. (2020). Readiness of Kindergarten Teachers to Face Online Learning During the Covid-19 Pandemic, Journal of Early Childhood Education.5(1):414-421.

[2] Erwin, Y., Arafat, Y., \& Wardiah, D., (2020). Utilization of Information and Communications Technology as a Learning Resource in the Digital Age. Journal of Management, Leadership, and Supervision of Education. Vol. 6, No. 44-51

[3] Alea, L. A., Fabrea, M. F., Roldan, R. D. A., \& Farooqi, A. Z. (2020). Teachers' Covid-19 Awareness, Distance Learning Education Experiences, and Perceptions towards Institutional Readiness and Challenges. International Journal of Learning, Teaching and Educational Research. Vol. 19, No. 6, pp. 127-144, June 2020. 127-144 https://doi.org/ 10.26803/ijlter.19.6.8

[4] Rahayu, R. P. \& Wirza, Y. (2020). Teachers' Perception of Online Learning during Pandemic Covid-19. Jurnal Penelitian Pendidikan Vol. 20, No. 3, 392-406. https://ejournal.upi.edu/ index.php/JER/article/view/29226

[5] Al-Maqtri, M. A. (2014). How Effective is Elearning in Teaching English?: A Case Study. Journal of Education and Human Development June 2014, Vol. 3, No. 2, pp. 647-669. https://www.researchgate.net/publication/3161584 87_How_Effective_is_E-learning_in_Teaching_ English_A_Case_Study

[6] Sofyana \& Rozaq, A. (2019). Whatsapp-based Combination Online Learning in The Employee Class of Informatics Engineering Study Program of PGRI Madiun University. Janapati: Jurnal Nasional Pendidikan dan Teknik Informatika. Vol. 8, No. 1, hal. 81-8 https://ejournal.undiksha.ac.id/ index.php/janapati/article/viewFile/17204/pdf

[7] Hasanah. (2020). Analysis of Student Online Learning Activities During the COVID-19 Pandemic. Journal of Education. 1 (1):3

[8] Tilaar, H. A. R. \& Nugroho, R. (2016). Introductory Education Policy to Fulfill Education Policy as a Public Policy. Yogyakarta: Student Library.

[9] Rohman, A. (2009). Political Education Ideology. Yogyakarta: Laks Bang Mediatama.

[10] Picciano, A. G. Seaman, J., Allen, I. E. (2010). Educational Transformation Through Online Learning: To $\mathrm{Be}$ or Not To Be. Journal of Asynchronous Learning Networks, Volume 14: Issue 4, https://files.eric.ed.gov/fulltext/EJ909909. 